\title{
Recent advances in central cardiovascular control: sex, ROS,
}

\section{gas and inflammation [version 1; peer review: 2 approved]}

\author{
Pauline M. Smith, Alastair V. Ferguson \\ Department of Biomedical and Molecular Sciences, Queen's University, Kingston, Ontario, K7L3N6, Canada
}

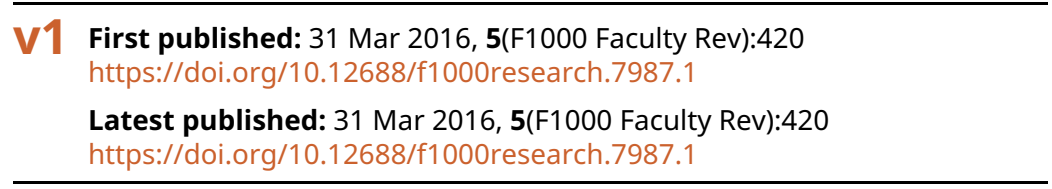

\section{Abstract}

The central nervous system (CNS) in concert with the heart and vasculature is essential to maintaining cardiovascular (CV) homeostasis. In recent years, our understanding of CNS control of blood pressure regulation (and dysregulation leading to hypertension) has evolved substantially to include (i) the actions of signaling molecules that are not classically viewed as CV signaling molecules, some of which exert effects at CNS targets in a non-traditional manner, and (ii) CNS locations not traditionally viewed as central autonomic cardiovascular centers. This review summarizes recent work implicating immune signals and reproductive hormones, as well as gasotransmitters and reactive oxygen species in the pathogenesis of hypertension at traditional CV control centers. Additionally, recent work implicating non-conventional CNS structures in CV regulation is discussed.

\section{Keywords}

hypertension, hydrogen sulfide, reactive oxygen species, reproductive hormones, cardiovascular homeostasis,

\section{Open Peer Review}

Approval Status

2

version 1

31 Mar 2016

Faculty Reviews are review articles written by the prestigious Members of Faculty Opinions. The articles are commissioned and peer reviewed before publication to ensure that the final, published version is comprehensive and accessible. The reviewers who approved the final version are listed with their names and affiliations.

1. Leo Renaud, University of Ottawa, Ottawa, Canada

\section{John Ciriello, University of Western Ontario,} London, Canada

Any comments on the article can be found at the end of the article. 
Corresponding author: Alastair V. Ferguson (avf@queensu.ca)

Competing interests: The authors declare that they have no competing interests.

Grant information: This work was supported by a grant from the Canadian Institutes for Health Research.

Copyright: ( 2016 Smith PM and Ferguson AV. This is an open access article distributed under the terms of the Creative Commons Attribution License, which permits unrestricted use, distribution, and reproduction in any medium, provided the original work is properly cited.

How to cite this article: Smith PM and Ferguson AV. Recent advances in central cardiovascular control: sex, ROS, gas and inflammation [version 1; peer review: 2 approved] F1000Research 2016, 5(F1000 Faculty Rev):420

https://doi.org/10.12688/f1000research.7987.1

First published: 31 Mar 2016, 5(F1000 Faculty Rev):420 https://doi.org/10.12688/f1000research.7987.1 


\section{Introduction}

According to the World Health Organization (WHO), cardiovascular (CV) disease accounts for approximately 17 million deaths a year worldwide $^{1}$, of which more than half (9.4 million) are attributable to complications of hypertension ${ }^{2}$. In 2008, a staggering $40 \%$ of adults over the age of 25 had been diagnosed with hypertension ${ }^{3}$.

The central nervous system (CNS) is essential to maintaining CV homeostasis. Traditional central autonomic CV control centers include the nucleus tractus solitarius (NTS), the rostral ventral lateral medulla (RVLM), and the caudal ventral lateral medulla in the brainstem; the parabrachial nucleus in the pons; and the paraventricular nucleus (PVN) in the hypothalamus. In addition, the area postrema (AP) in the hindbrain, and the organum vasculosum of the lamina terminalis (OVLT) and subfornical organ (SFO) in the forebrain, are sensory circumventricular organs (CVOs) characterized by the presence of a wide variety of receptors and the lack of the normal blood-brain barrier, which have also been implicated in central $\mathrm{CV}$ regulation. The renin-angiotensin aldosterone system (RAAS) has also been extensively implicated as a critical signaling system, components of which play central roles both as circulating hormones and as CNS neurotransmitters in the regulation of blood pressure (BP). There is growing evidence that the development and progression of hypertension involves dysregulation of the sympathetic nervous system (SNS) (SNS over-activity) (for review, see 4-6) and activation of the RAAS ${ }^{7,8}$.

Over the past 20 years, our understanding of CNS control of BP regulation (and dysregulation leading to hypertension) has evolved substantially. This review will summarize some of these paradigm shifts, focussing primarily on signaling molecules that either (i) are not classically viewed as $\mathrm{CV}$ signaling molecules (i.e. immune signals and reproductive hormones) or (ii) exert effects at CNS targets in a non-traditional manner, acting via membrane receptor-independent signaling mechanisms (i.e. gasotransmitters and reactive oxygen species [ROS]), all of which have been shown to have profound effects on the central control of BP. CNS structures, not conventionally thought of as CV control centers but that more recently have been shown to influence $\mathrm{CV}$ regulation, are also discussed.

\section{Inflammation and immune regulators as modulators of cardiovascular regulation and contributors to hypertension}

Although it had been speculated decades ago that there was a relationship between the immune system and hypertension", the demonstration of systemic markers of inflammation in patients with essential hypertension in the early $2000 \mathrm{~s}^{10,11}$ was a catalyst for renewed interest in the relationship between hypertension and the immune system. Emerging evidence suggests that both the innate and acquired immune systems are activated in hypertension, as inflammations in the kidney, vasculature (arteries), and CNS have all been shown to be involved in the pathogenesis of hypertension.

As an immediate first-line defence mechanism to infections or tissue injury, the innate immune system initiates a generalized inflammatory response involving dendritic cells, macrophages, natural killer (NK) T cells, and Toll-like receptors (TLRs), all of which have been shown to be activated in hypertension.
Dendritic cell activation has been shown to promote hypertension by stimulating T-cell proliferation which infiltrates both the kidney and arterial walls ${ }^{12,13}$. Similarly, macrophage infiltration of the kidney and arteries has been documented in experimental models of hypertension, and a decrease in macrophage infiltration is associated with an improvement of hypertension in these models of hypertension $^{14-17}$. Recently, NK T-cell activation and TLRs (TLR4, in particular) have been suggested to play a role in hypertensionrelated inflammation ${ }^{18,19}$.

The adaptive immune system responds to specific antigens and involves antigen presentation, lymphocyte activation, and antibody production. T cells have been shown to play a role in angiotensin II (ANG II)-induced hypertension ${ }^{20}$ whereas endogenously produced ANG II increases T-cell activation ${ }^{21}$. Pro-inflammatory T-cell activation and the subsequent release of pro-inflammatory cytokines are associated with hypertension ${ }^{22-24}$ whereas inhibition or genetic ablation of the B7/CD28 $\mathrm{T}$ cell costimulatory pathway has been shown to prevent experimental hypertension ${ }^{12}$. $\mathrm{RAG}^{-1^{-1}}$ mice and SCID mice, which lack both $\mathrm{T}$ and $\mathrm{B}$ cells, exhibited a blunted hypertensive response to ANG II infusion ${ }^{20,25}$, a response that returned when $\mathrm{T}$ cells were transferred into RAG-1/- mice $^{20}$. $\mathrm{T}$ cell-produced cytokines (such as tumor necrosis factor alpha, or TNF $\alpha$ ) and many of the interleukins (such as IL-6) have been shown to play a role in hypertension. TNF $\alpha$ antagonism ${ }^{20,26}$ or genetic knockout of IL- $6^{27}$ has been shown to blunt ANG II-induced hypertension. The presence of agonist antibodies to ANG II receptors has been identified in a number of conditions that are characterized by elevated BP, such as preeclampsia ${ }^{28,29}$, refractory hypertension ${ }^{30,31}$, and malignant hypertension ${ }^{32}$.

Many studies have suggested that arterial inflammation within specific CNS locations is involved in the pathogenesis of hypertension. A role for inflammation in the NTS, a pivotal region for regulating arterial pressure baroreceptor reflex sensitivity, has been suggested in the development of hypertension, as studies have shown not only leukocyte accumulation within the NTS microvasculature ${ }^{33}$ but also changes in gene expression of a variety of inflammatory molecules ${ }^{34,35}$ and neurotrophic factors ${ }^{36}$ in the NTS of spontaneously hypertensive rats (SHRs).

In addition, many of the cytokines, released as a consequence of immune system activation, have been shown to directly influence cardiovascular control centers in the CNS. Microinjection of IL-6 into the NTS attenuates baroreceptor function ${ }^{37}$ and leads to speculation that abnormal gene expression of IL-6 in the NTS may be associated with hypertension. Augmentation of IL-1 $\beta$, IL-6, or TNF- $\alpha$ expression and increased ROS observed in the RVLM following chronic intraperitoneal lipopolysaccharide administration have been suggested to be contributing factors to neurogenic hypertension induced by systemic inflammation ${ }^{38}$.

Early studies identified the anteroventral third ventricle (AV3V), a broad-based region located along the wall of the third ventricle which includes the OVLT, as a critical CNS structure in the pathogenesis of hypertension ${ }^{39}$. A more recent study not only confirmed that lesions of the AV3V region attenuate ANG II-induced hypertension but also implicated immune system involvement as AV3V lesions eliminated circulating T-cell activation and 
vascular infiltration normally observed in response to ANG II administration $^{40}$. IL-1 $\beta$ has been shown to influence the excitability of SFO neurons ${ }^{41}$, and recent studies have demonstrated that microinjection of IL-1 $\beta$ (and of TNF $\alpha$ ) into SFO increases $\mathrm{BP}$ and renal sympathetic nerve activity (SNA) ${ }^{42}$.

The PVN, a hypothalamic autonomic control center with welldocumented roles in $\mathrm{CV}$ regulation, has been implicated as a CNS structure in which immune signals may act to cause hypertension. Chronic ANG II infusion causes the expression of proinflammatory cytokines and markers of oxidative stress in the PVN, effects blocked by central administration of TNF $\alpha$ blocker ${ }^{26}$. Angiotensin-converting enzyme 2 (ACE2) overexpression in the PVN has also been shown to attenuate both ANG II-induced hypertension and expression of the pro-inflammatory cytokines TNF $\alpha$, IL-1 $1 \beta$, and IL- 6 in the PVN ${ }^{43}$. Blockade of nuclear factorkappa-B (NFKB), a prominent transcription factor that governs inflammatory responses, in the PVN of rats resulted in decreased $\mathrm{BP}$, pro-inflammatory cytokines, and ROS, as well as upregulation of key protective anti-hypertensive RAAS components, suggesting an important role for NFKB in PVN in the hypertensive response ${ }^{44}$. Finally, rats fed a high-salt diet demonstrated increased expression of IL- $1 \beta$ and decreased expression of the anti-inflammatory cytokine IL-10, in the PVN. These expression levels were augmented by stimulation of ROS production within the $\mathrm{PVN}^{45}$.

\section{Reproductive hormones and cardiovascular regulation}

The interest in the role of sex hormones in hypertension has been driven by a number of observations regarding sexual dimorphism in BP regulation in humans and animals. Epidemiological findings that prior to menopause the prevalence of essential hypertension is lower in women than in men of the same age ${ }^{46}$ and that young women have lower resting SNA than men $^{47}$, differences that disappear after menopause, suggest that estradiol is important in BP regulation and, in fact, may protect against hypertension. Findings that estradiol administration attenuates increases in BP normally exhibited by intact males and ovariectomized females, and prevents development of hypertension in experimental models of hypertension ${ }^{48,49}$, suggest a role for estradiol in the regulation of BP.

Studies in humans and animals suggest that exogenous testosterone may also play a crucial role in BP regulation. In humans, low testosterone levels have been correlated with higher $\mathrm{BP}^{50,51}$ whereas testosterone replacement has been shown to cause significant reductions in $\mathrm{BP}^{52,53}$, suggesting a role for testosterone in BP regulation. Moreover, in experimental models of hypertension high BP develops more rapidly and becomes more severe in the male than in the female, effects which were shown to be androgen-dependent ${ }^{48,54,55}$. Further support for a role of testosterone in the etiology of hypertension is derived from studies showing that castration prevents the development of hypertension in SHR rats ${ }^{56}$.

Evidence for a role for central actions of estradiol on BP regulation is derived from a variety of sources. Firstly, many of the CNS sites with well-documented roles in $\mathrm{CV}$ regulation have been shown to possess estrogen receptors $(\mathrm{ER} \alpha \text { and } \mathrm{ER} \beta)^{57-61}$. Moreover, intracerebroventicular (icv) administration of estradiol in ovariectomized mice and in male mice attenuated the increase in BP normally elicited by ANG II $^{62}$. In rats, aldosterone/salt-induced hypertension is exhibited by intact males and ovariectomized females, effects attenuated by activation of central ER receptors. Central ER blockade ${ }^{63}$ or icv injections of small interfering RNA-ER $\alpha$ (siRNA-ER $\alpha$ ) or siRNA-ER $\beta^{64}$, on the other hand, augmented aldosterone-induced hypertension in intact females.

Further to these findings, estradiol has been shown to act via ER $\alpha$ or ER $\beta$ (or both) at specific brain regions in both males and females to influence sympathetic outflow and baroreflex function. The AP and SFO predominantly express ER $\alpha^{57-62}$, and estradiol has been shown to decrease the activity of $\mathrm{AP}^{65}$ and $\mathrm{SFO}$ neurons ${ }^{66}$, and inhibits ANG II activation of $\mathrm{AP}^{67}$ and $\mathrm{SFO}$ neurons ${ }^{66}$, whereas genetic knockdown of ER $\alpha$ in the SFO enhances ANG II-induced hypertension in female mice ${ }^{68}$.

Estrogen actions at ER $\beta$ in PVN inhibit hypertensive effects of glutamate activation ${ }^{69}$. In the RVLM, estradiol actions at ER $\beta$ receptors have been shown to cause decreases in BP in normotensive rats $^{70}$ and to attenuate aldosterone-induced increases in SNA and $\mathrm{BP}^{64}$ whereas ER $\beta$ knockdown in RVLM or PVN results in the augmentation of aldosterone-induced increases in SNA and $\mathrm{BP}^{64}$, effects that are not seen in intact females ${ }^{64}$.

Relaxin, a member of the insulin family best known for its role in pregnancy, has also been shown to influence BP. Early studies revealed that chronic intravenous (iv) administration of relaxin elicited a decrease in BP in SHRs ${ }^{71}$. Relaxin binding sites and relaxin receptors have been shown to be widely distributed throughout the brain, including the SFO, NTS, and $\mathrm{PVN}^{72}$, suggesting that relaxin may be involved in the central control of BP. Hypertensive effects of central administration of relaxin into the dorsal third ventricle are totally abolished by lesions of the $\mathrm{SFO}^{73}$, identifying this $\mathrm{CVO}$ as one central target mediating these cardiovascular effects. A recent study demonstrating that acute microinjection of relaxin-2 into the PVN increased sympathetic outflow and BP in SHR, whereas chronic PVN administration caused a profound increase in BP in normotensive rats ${ }^{74}$, supports the conclusion that there are multiple central targets for this reproductive hormone/neurotransmitter. Moreover, this same study revealed that neutralization of endogenous relaxin reduced BP in SHR but had no significant effect in $\mathrm{WKY}^{74}$, suggesting a role for relaxin in the pathogenesis of hypertension.

Another reproductive peptide that warrants further investigation into its potential contribution to the pathogenesis of hypertension is prolactin, a hormone best known for its involvement in lactation and reproduction. Very few studies have investigated the role of prolactin in the central control of $\mathrm{CV}$ regulation despite epidemiological evidence suggesting correlations between circulating prolactin levels and increased BP. Plasma prolactin has been shown to be elevated in patients with essential hypertension ${ }^{75}$ and preeclampsia ${ }^{76,77}$. Furthermore, higher plasma prolactin levels have been shown to be associated with increased risk of hypertension in menopausal ${ }^{78}$ and post-menopausal ${ }^{79}$ women and in preeclampsia ${ }^{54}$. Prolactin receptors are widely distributed throughout the body ${ }^{80}$ 
and brain $^{81}$. mRNA for the prolactin receptor has been reported in the $\mathrm{PVN}^{81,82}$, and we have identified the presence of the prolactin receptor at levels similar to the AT1 receptor in the $\mathrm{SFO}^{83}$. However, to our knowledge, studies investigating the CV consequences of central administration of prolactin (icv or microinjection into discrete brain nuclei) on $\mathrm{BP}$, or the effects of prolactin on neuronal excitability in central CV control centers, are lacking.

\section{Gasotransmitters and cardiovascular regulation: hydrogen sulfide}

Gasotransmitters are endogenously produced membrane permeable gas molecules which act at specific, targeted cells via membrane receptor-independent signaling mechanisms to exert well-defined physiological effects. The action(s) of nitric oxide (NO) and carbon monoxide (CO) at peripheral tissues and in the CNS to influence cardiovascular regulation are well documented ${ }^{84,85}$. More recently, a third gasotransmitter, hydrogen sulfide $\left(\mathrm{H}_{2} \mathrm{~S}\right)$, an environmental air pollutant with well-known deleterious health effects, has been identified and suggested to play a role in the pathogenesis of hypertension. $\mathrm{H}_{2} \mathrm{~S}$ is endogenously produced from catalysis of L-cysteine by using four enzymes: cystathionine $\beta$-synthase (CBS), cystathionine $\gamma$-lysase (CSE), or 3-mercaptopyruvate sulfur transferase (3MST) in tandem with cysteine aminotransferase (CAT). CBS is highly expressed in the CNS where it produces $\mathrm{H}_{2} \mathrm{~S}$ from L-cysteine $^{86}$, whereas CSE is the predominant enzyme expressed in the myocardium and vasculature smooth muscle cells ${ }^{87}$. Though predominantly found in the mitochondria where they work in tandem to produce $\mathrm{H}_{2} \mathrm{~S}, 3 \mathrm{MST}$ and CAT are also expressed in the brain and vascular endothelium ${ }^{88}$. In addition, $\mathrm{H}_{2} \mathrm{~S}$ can be produced in red blood cells by the conversion of polysulfides which are obtained from dietary sources ${ }^{89}$.

Evidence for a role of $\mathrm{H}_{2} \mathrm{~S}$ in the pathogenesis of hypertension is suggested by the observation that plasma $\mathrm{H}_{2} \mathrm{~S}$ concentrations are lower in patients with grade 2 or grade 3 hypertension, portal hypertension, and pulmonary hypertension ${ }^{90-92}$ and in preeclampsia where plasma $\mathrm{H}_{2} \mathrm{~S}$ levels and placental CBS mRNA expression are decreased ${ }^{93,94}$.

$\mathrm{H}_{2} \mathrm{~S}$ has been shown to be endogenously produced in peripheral vascular tissues and has been demonstrated to be a potent vasodilator, causing vasorelaxation in mesenteric arteries ${ }^{95}$, aortic rings ${ }^{96,97}$, the ductus arteriosis ${ }^{96}$, and pulmonary arteries ${ }^{98}$ via actions on vascular smooth muscle cells. Unlike its gasotransmitter counterparts, $\mathrm{NO}$ and $\mathrm{CO}$, vascular smooth muscle relaxation occurs independently of cGMP pathway activation. Activations of $\mathrm{Ca}^{2+}$-activated potassium channels $(\mathrm{BKCa})^{99}$, ATP-sensitive potassium channels $\left(\mathrm{K}_{\text {ATP }}\right)^{100}, \mathrm{Kv} 7$ voltage-gated potassium channels ${ }^{97}$, and cytochrome P-450 2C (Cyp2C $)^{99}$ have all been implicated as mechanisms of the $\mathrm{H}_{2} \mathrm{~S}$ vasorelaxation.

A bolus iv injection of $\mathrm{H}_{2} \mathrm{~S}$ elicited an immediate depressor response in normotensive rats ${ }^{100}$ whereas chronic intraperitoneal administration of $\mathrm{H}_{2} \mathrm{~S}$ decreases $\mathrm{BP}$ in hypertensive rats ${ }^{101-104}$. These findings, along with the fact that mice lacking CSE exhibit hypertension and reduced endothelium-dependent vasorelaxation ${ }^{105}$, provide evidence of a direct role for $\mathrm{H}_{2} \mathrm{~S}$ in $\mathrm{BP}$ regulation.
A role for $\mathrm{H}_{2} \mathrm{~S}$ in the central control of BP stems from studies demonstrating that icv administration of $\mathrm{H}_{2} \mathrm{~S}$ has been shown to dosedependently decrease BP, effects which are followed by potent long-lasting hypertension actions attributed to modulation of $\mathrm{H}_{2} \mathrm{~S}$ on $\mathrm{K}_{\text {ATP }}$ channels and $\alpha$ adrenergic stimulation, respectively ${ }^{106}$. Furthermore, microinjection of $\mathrm{H}_{2} \mathrm{~S}$ into discrete brain nuclei known for their involvement in $\mathrm{CV}$ regulation has also been shown to affect BP. $\mathrm{H}_{2} \mathrm{~S}$ administration into the RVLM elicits decreases in BP, effects again mediated by $\mathrm{K}_{\text {ATP }}$ channels ${ }^{107}$, whereas similar microinjections into the $\mathrm{PVN}^{108}$ and $\mathrm{SFO}^{109}$ have been shown to dose-dependently increase BP. Moreover, $\mathrm{H}_{2} \mathrm{~S}$ has been shown to influence the excitability of neurons in the $\mathrm{NTS}^{110}, \mathrm{PVN}^{111}$, and $\mathrm{SFO}^{109}$, CNS areas involved in $\mathrm{CV}$ regulation.

\section{Reactive oxygen species and cardiovascular control}

When produced at appropriate concentrations, ROS have been implicated in the regulation of many critical physiological processes, including cell signaling, maintenance of appropriate vascular tone, inflammation, and immune responses. ROS overproduction, on the other hand, is a feature common to a number of pathological conditions, including hypertension.

A role for ROS in hypertension is suggested in humans as a positive correlation between BP and biomarkers of oxidative stress in patients with essential hypertension has been reported ${ }^{112,113}$. Furthermore, mice lacking nicotinamide adenine dinucleotide phosphate (NADPH) oxidases, key enzymes in the production of ROS, are protected against experimental hypertension ${ }^{114}$, whereas overexpression potentiates ANG II-induced hypertension ${ }^{115}$.

ROS production in specific CNS cardiovascular control centers, including both brain stem (NTS, RVLM) and hypothalamic (PVN) nuclei, and within the CVOs (SFO) has been shown to play a role in neurogenic hypertension ${ }^{116-118}$. Superoxide dismutase (SOD), an enzyme that metabolizes superoxide, overexpression in the brain abolished the hypertensive response normally observed in response to icv ANG II administration ${ }^{119}$, whereas specific SOD3 deletion in the SFO increased baseline BP and potentiated ANG II-induced increases in $\mathrm{BP}^{120}$. Interestingly, this same study showed that ROS in the SFO leads to infiltration by activated lymphocytes in the peripheral vasculature ${ }^{120}$, linking oxidative stress in the CNS with immune activation in the periphery, which in concert would serve to intensify hypertension.

A high-salt diet increases NADPH oxidase (NOX-2 and NOX-4) expression in the PVN, whereas microinjection of amino-triazole (ATZ), a catalase inhibitor which increases ROS, into the PVN augments renovascular hypertension as well as increasing BP in normal rats $^{45}$.

\section{A role for 'other' central nervous system structures in the central control of blood pressure}

This review has focussed on actions of non-traditional CV signaling molecules at CNS structures with well-documented roles in $\mathrm{CV}$ regulation. Another emerging area that warrants mention is the role of CNS regions not classically viewed as CV control centers that have been suggested to play a role in the pathogenesis of 
hypertension, secondarily or as a co-morbidity to other disease states. For example, the explosion of obesity research further to the discovery of leptin in the $1990 \mathrm{~s}^{121}$ has highlighted the involvement of a number of CNS autonomic control centers not typically viewed as $\mathrm{CV}$ control centers, such as the arcuate nucleus and the anterior hypothalamus, in the pathogenesis of hypertension as a consequence of direct actions of metabolic signals in these areas (for review, see 122,123). Furthermore, many metabolic signals associated with obesity have been demonstrated to influence BP regulation via actions at the 'classical' CNS CV control centers. Further study of the actions of traditional CV signals (such as ANG II) within these non-traditional CV CNS centers may elucidate previously unknown roles of these regions in normal $\mathrm{CV}$ regulation.

\section{Conclusions}

In this brief review, we have highlighted some emerging new perspectives which over the past 20 years contributed new and important information to the evolution of our understanding of CNS mechanisms involved in central CV control. The areas we have chosen to discuss are far from an exhaustive list of what is new and interesting, but do emphasize that this is a continually developing area of research with an inherent complexity associated with the requirement for integration of diverse autonomic systems. This points us in the direction of understanding that we perhaps should not expect to consider either single brain areas or single signalling molecules as "cardiovascular" at the expense of also describing their roles in other systems. Such conclusions point us to the broader perspective that all of these brain areas, signaling molecules, and autonomic systems contribute to the complex homeostatic regulation which maintains our "milieu interior" in a state of optimal health.

\section{Competing interests}

The authors declare that they have no competing interests.

\section{Grant information}

This work was supported by a grant from the Canadian Institutes for health Research.
1. World Health Organization: Causes of Death 2008 Reference Source

2. Lim SS, Vos T, Flaxman AD, et al.: A comparative risk assessment of burden of disease and injury attributable to 67 risk factors and risk factor clusters in 21 regions, 1990-2010: a systematic analysis for the Global Burden of Disease Study 2010. Lancet. 2012; 380(9859): 2224-60. PubMed Abstract | Publisher Full Text | Free Full Text

3. World Health Organization. Global status report on noncommunicable diseases 2011.

4. DiBona GF: Sympathetic nervous system and hypertension. Hypertension. 2013; 61(3): 556-60. PubMed Abstract | Publisher Full Text

5. Guyenet PG: The sympathetic control of blood pressure. Nat Rev Neurosci 2006; 7(5): 335-46.

PubMed Abstract | Publisher Full Text

6. Parati G, Esler M: The human sympathetic nervous system: its relevance in hypertension and heart failure. Eur Heart J. 2012; 33(9): 1058-66. PubMed Abstract | Publisher Full Text

7. Leenen $\mathrm{FH}$ : Actions of circulating angiotensin II and aldosterone in the brain contributing to hypertension. Am J Hypertens. 2014; 27(8): 1024-32. PubMed Abstract | Publisher Full Text

8. Moon JY: Recent Update of Renin-angiotensin-aldosterone System in the Pathogenesis of Hypertension. Electrolyte Blood Press. 2013; 11(2): 41-5. PubMed Abstract | Publisher Full Text | Free Full Text

9. White FN, Grollman A: Autoimmune Factors Associated With Infarction Of The Kidney. Nephron. 1964; 1(2): 93-102. PubMed Abstract | Publisher Full Text

10. Chae CU, Lee RT, Rifai $N$, et al: Blood pressure and inflammation in apparently healthy men. Hypertension. 2001; 38(3): 399-403. PubMed Abstract | Publisher Full Text

11. Engström G, Janzon L, Berglund G, et al:: Blood pressure increase and incidence of hypertension in relation to inflammation-sensitive plasma proteins. Arterioscler Thromb Vasc Biol. 2002; 22(12): 2054-8. PubMed Abstract | Publisher Full Text

12. $\mathrm{F}$ Vinh $\mathrm{A}$, Chen $\mathrm{W}$, Blinder $\mathrm{Y}$, et al:: Inhibition and genetic ablation of the $\mathrm{B} 7$ I CD28 T-cell costimulation axis prevents experimental hypertension. Circulation. 2010; 122(24): 2529-37.

PubMed Abstract | Publisher Full Text | Free Full Text | F1000 Recommendation

13. F Xiao L, Kirabo A, Wu J, et al:: Renal Denervation Prevents Immune Cell Activation and Renal Inflammation in Angiotensin II-Induced Hypertension. Circ Res. 2015; 117(6): 547-57.

PubMed Abstract | Publisher Full Text | Free Full Text | F1000 Recommendation
14. Boesen EI, Williams DL, Pollock JS, et al.: Immunosuppression with mycophenolate mofetil attenuates the development of hypertension and albuminuria in deoxycorticosterone acetate-salt hypertensive rats. Clin Exp Pharmacol Physiol. 2010; 37(10): 1016-22. PubMed Abstract | Publisher Full Text | Free Full Text

15. Muller DN, Shagdarsuren E, Park JK, et al.: Immunosuppressive treatment protects against angiotensin II-induced renal damage. Am J Pathol. 2002; 161(5): 1679-93.

PubMed Abstract | Publisher Full Text | Free Full Text

16. Rodríguez-Iturbe B, Pons $\mathrm{H}$, Quiroz $\mathrm{Y}$, et al:: Mycophenolate mofetil prevents salt-sensitive hypertension resulting from angiotensin II exposure. Kidney Int 2001; 59(6): 2222-32.

PubMed Abstract | Publisher Full Text

17. Rodríguez-Iturbe B, Quiroz $\mathrm{Y}$, Nava M, et al:: Reduction of renal immune cell infiltration results in blood pressure control in genetically hypertensive rats. Am J Physiol Renal Physiol. 2002; 282(2): F191-201. PubMed Abstract | Publisher Full Text

18. F Bomfim GF, Dos Santos RA, Oliveira MA, et al.: Toll-like receptor 4 contributes to blood pressure regulation and vascular contraction in spontaneously hypertensive rats. Clin Sci (Lond). 2012; 122(11): 535-43. PubMed Abstract | Publisher Full Text | Free Full Text | F1000 Recommendation

19. F Sollinger D, Eißler R, Lorenz S, et al:: Damage-associated molecular pattern activated Toll-like receptor 4 signalling modulates blood pressure in L-NAMEinduced hypertension. Cardiovasc Res. 2014; 101(3): 464-72. PubMed Abstract | Publisher Full Text | F1000 Recommendation

20. F Guzik TJ, Hoch NE, Brown KA, et al:: Role of the T cell in the genesis of angiotensin II induced hypertension and vascular dysfunction. J Exp Med. 2007; 204(10): 2449-60.

PubMed Abstract | Publisher Full Text | Free Full Text | F1000 Recommendation

21. Hoch NE, Guzik TJ, Chen W, et al.: Regulation of T-cell function by endogenously produced angiotensin II. Am J Physiol Regul Integr Comp Physiol. 2009; 296(2): R208-16.

PubMed Abstract | Publisher Full Text | Free Full Text

22. Bautista LE, Vera LM, Arenas IA, et al:: Independent association between inflammatory markers (C-reactive protein, interleukin-6, and TNF-alpha) and essential hypertension. J Hum Hypertens. 2005; 19(2): 149-54. PubMed Abstract | Publisher Full Text

23. Chamarthi B, Williams GH, Ricchiuti V, et al.: Inflammation and hypertension: the interplay of interleukin-6, dietary sodium, and the renin-angiotensin system in humans. Am J Hypertens. 2011; 24(10): 1143-8. PubMed Abstract | Publisher Full Text | Free Full Text

24. F Madhur MS, Lob HE, McCann LA, et al.: Interleukin 17 promotes angiotensin 
II-induced hypertension and vascular dysfunction. Hypertension. 2010; 55(2): $500-7$.

PubMed Abstract | Publisher Full Text | Free Full Text | F1000 Recommendation

25. Crowley SD, Song Y, Lin EE, et al:: Lymphocyte responses exacerbate angiotensin II-dependent hypertension. Am J Physiol Regul Integr Comp Physiol. 2010; 298(4): R1089-97.

PubMed Abstract | Publisher Full Text | Free Full Text

26. Sriramula S, Cardinale JP. Francis J: Inhibition of TNF in the brain reverses alterations in RAS components and attenuates angiotensin II-induced hypertension. PLoS One. 2013; 8(5): e63847.

PubMed Abstract | Publisher Full Text | Free Full Text

27. Lee DL, Sturgis LC, Labazi $\mathrm{H}$, et al:: Angiotensin II hypertension is attenuated in interleukin-6 knockout mice. Am J Physiol Heart Circ Physiol. 2006; 290(3): H935-40.

PubMed Abstract | Publisher Full Text

28. Siddiqui $\mathrm{AH}$, Irani RA, Zhang W, et al.: Angiotensin receptor agonistic autoantibody-mediated soluble fms-like tyrosine kinase-1 induction contributes to impaired adrenal vasculature and decreased aldosterone production in preeclampsia. Hypertension. 2013; 61(2): 472-9. PubMed Abstract | Publisher Full Text | Free Full Text

29. Wallukat G, Homuth V, Fischer $\mathrm{T}$, et al:: Patients with preeclampsia develop agonistic autoantibodies against the angiotensin AT1 receptor. J Clin Invest. 1999; 103(7): 945-52.

PubMed Abstract | Publisher Full Text | Free Full Text

30. Liao Y, Wei YM, Wang M, et al.: Autoantibodies against AT1-receptor and alpha1-adrenergic receptor in patients with hypertension. Hypertens Res. 2002; 25(4): 641-6.

PubMed Abstract | Publisher Full Text

31. Zhu F, Sun YX, Liao YH, et al:: Agonistic $\mathbf{A} \mathbf{T}^{1}$ receptor autoantibody increases in serum of patients with refractory hypertension and improves $\mathrm{Ca}^{2+}$ mobilization in cultured rat vascular smooth muscle cells. Cell Mol Immunol. 2008; 5(3): 209-17. PubMed Abstract | Publisher Full Text | Free Full Text

32. F Dragun $\mathrm{D}$, Müller $\mathrm{DN}$, Bräsen $\mathrm{JH}$, et al:: Angiotensin II type 1-receptor activating antibodies in renal-allograft rejection. N Engl J Med. 2005; 352(6): 558-69. PubMed Abstract | Publisher Full Text | F1000 Recommendation

33. Waki H, Hendy EB, Hindmarch CC, et al:: Excessive leukotriene B4 in nucleus tractus solitarii is prohypertensive in spontaneously hypertensive rats. Hypertension. 2013; 61(1): 194-201.

PubMed Abstract | Publisher Full Text | Free Full Text

34. Gouraud SS, Waki H, Bhuiyan ME, et al.: Down-regulation of chemokine Ccl5 gene expression in the NTS of SHR may be pro-hypertensive. J Hypertens. 2011; 29(4): 732-40.

PubMed Abstract | Publisher Full Text

35. Waki $\mathrm{H}$, Gouraud SS, Maeda M, et al:: Contributions of vascular inflammation in the brainstem for neurogenic hypertension. Respir Physiol Neurobiol. 2011; 178(3): 422-8.

PubMed Abstract | Publisher Full Text

36. F Gouraud SS, Takagishi M, Kohsaka A, et al.: Altered neurotrophic factors expression profiles in the nucleus of the solitary tract of spontaneously hypertensive rats. Acta Physiol (Oxf). 2016; 216(3): 346-57. PubMed Abstract | Publisher Full Text | F1000 Recommendation

37. Takagishi M, Waki H, Bhuiyan ME, et al.: IL-6 microinjected in the nucleus tractus solitarii attenuates cardiac baroreceptor reflex function in rats. $A m$ Physiol Regul Integr Comp Physiol. 2010; 298(1): R183-90.

PubMed Abstract | Publisher Full Tex

38. F Wu KLH, Chan SHH, Chan JY: Neuroinflammation and oxidative stress in rostral ventrolateral medulla contribute to neurogenic hypertension induced by systemic inflammation. J Neuroinflammation. 2012; 9: 212 .

PubMed Abstract | Publisher Full Text | Free Full Text | F1000 Recommendation

39. Buggy J, Fink GD, Johnson AK, et al.: Prevention of the development of renal hypertension by anteroventral third ventricular tissue lesions. Circ Res. 1977; 40(5 Suppl 1): I110-7.

PubMed Abstract

40. F Marvar PJ, Thabet SR, Guzik TJ, et al:: Central and peripheral mechanisms of T-lymphocyte activation and vascular inflammation produced by angiotensin II-induced hypertension. Circ Res. 2010; 107(2): 263-70. PubMed Abstract | Publisher Full Text | Free Full Text | F1000 Recommendation

41. Desson SE, Ferguson AV: Interleukin 1beta modulates rat subfornical organ neurons as a result of activation of a non-selective cationic conductance. J Physiol. 2003; 550(Pt 1): 113-22.

PubMed Abstract | Publisher Full Text | Free Full Text

42. F Wei SG, Yu Y, Zhang ZH, et al:: Proinflammatory cytokines upregulate sympathoexcitatory mechanisms in the subfornical organ of the rat. Hypertension. 2015; 65(5): 1126-33.

PubMed Abstract | Publisher Full Text | Free Full Text | F1000 Recommendation

43. Sriramula S, Cardinale JP, Lazartigues E, et al:: ACE2 overexpression in the paraventricular nucleus attenuates angiotensin II-induced hypertension. Cardiovasc Res. 2011; 92(3): 401-8. PubMed Abstract | Publisher Full Text | Free Full Text

44. F Yu XJ, Zhang DM, Jia LL, et al:: Inhibition of NF-kB activity in the hypothalamic paraventricular nucleus attenuates hypertension and cardiac hypertrophy by modulating cytokines and attenuating oxidative stress. Toxicol Appl Pharmacol. 2015; 284(3): 315-22.

PubMed Abstract | Publisher Full Text | F1000 Recommendation

45. $\mathrm{F}$ Zhang M, Qin DN, Suo YP, et al.: Endogenous hydrogen peroxide in the hypothalamic paraventricular nucleus regulates neurohormonal excitation in high salt-induced hypertension. Toxicol Lett. 2015; 235(3): 206-15. PubMed Abstract | Publisher Full Text | F1000 Recommendation

46. F Cutler JA, Sorlie PD, Wolz M, et al:: Trends in hypertension prevalence, awareness, treatment, and control rates in United States adults between 1988-1994 and 1999-2004. Hypertension. 2008; 52(5): 818-27. PubMed Abstract | Publisher Full Text | F1000 Recommendation

47. Hart EC, Charkoudian N: Sympathetic neural regulation of blood pressure: influences of sex and aging. Physiology (Bethesda). 2014; 29(1): 8-15. PubMed Abstract | Publisher Full Text

48. lams SG, Wexler BC: Inhibition of the development of spontaneous hypertension in SH rats by gonadectomy or estradiol. $J$ Lab Clin Med. 1979; 94(4): 608-16. PubMed Abstract

49. Sasaki T, Ohno Y, Otsuka K, et al.: Oestrogen attenuates the increases in blood pressure and platelet aggregation in ovariectomized and salt-loaded Dahl saltsensitive rats. J Hypertens. 2000; 18(7): 911-7. PubMed Abstract | Publisher Full Text

50. Fogari R, Preti $P$, Zoppi A, et al:: Serum testosterone levels and arterial blood pressure in the elderly. Hypertens Res. 2005; 28(8): 625-30.

PubMed Abstract | Publisher Full Text

51. Svartberg J, von Mühlen D, Schirmer $\mathrm{H}$, et al:: Association of endogenous testosterone with blood pressure and left ventricular mass in men. The Tromse Study. Eur J Endocrinol. 2004; 150(1): 65-71.

PubMed Abstract | Publisher Full Text

52. Bhattacharya RK, Khera M, Blick G, et al.: Effect of $\mathbf{1 2}$ months of testosterone replacement therapy on metabolic syndrome components in hypogonadal men: data from the Testim Registry in the US (TRiUS). BMC Endocr Disord. 2011; 11: 18. PubMed Abstract | Publisher Full Text | Free Full Text

53. Li JY, Zhu JC, Dou JT, et al:: Effects of androgen supplementation therapy on partial androgen deficiency in the aging male: a preliminary study. Aging Male. 2002; 5(1): 47-51

PubMed Abstract | Publisher Full Text

54. Dahl LK, Knudsen KD, Ohanian EV, et al.: Role of the gonads in hypertensionprone rats. J Exp Med. 1975; 142(3): 748-59. PubMed Abstract | Free Full Text

55. Ouchi Y, Share L, Crofton JT, et al.: Sex difference in the development of deoxycorticosterone-salt hypertension in the rat. Hypertension. 1987; 9(2): 172-7. PubMed Abstract | Publisher Full Text

56. Chen YF, Naftilan AJ, Oparil S: Androgen-dependent angiotensinogen and renin messenger RNA expression in hypertensive rats. Hypertension. 1992; 19(5): 456-63.

PubMed Abstract | Publisher Full Text

57. Laflamme N, Nappi RE, Drolet G, et al.: Expression and neuropeptidergic characterization of estrogen receptors (ERalpha and ERbeta) throughout the rat brain: anatomical evidence of distinct roles of each subtype. $J$ Neurobiol. 1998; 36(3): 357-78

PubMed Abstract | Publisher Full Text

58. Rosas-Arellano MP, Solano-Flores LP, Ciriello J: Co-localization of estrogen and angiotensin receptors within subfornical organ neurons. Brain Res. 1999; 837(1-2): 254-62.

PubMed Abstract | Publisher Full Text

59. Simerly RB, Chang $C$, Muramatsu $M$, et al: Distribution of androgen and estrogen receptor mRNA-containing cells in the rat brain: an in situ hybridization study. J Comp Neurol. 1990; 294(1): 76-95. PubMed Abstract | Publisher Full Text

60. Somponpun SJ, Johnson AK, Beltz T, et al.: Estrogen receptor-alpha expression in osmosensitive elements of the lamina terminalis: regulation by hypertonicity Am J Physiol Regul Integr Comp Physiol. 2004; 287(3): R661-9. PubMed Abstract | Publisher Full Text

61. Spary EJ, Maqbool A, Batten TF: Oestrogen receptors in the central nervous system and evidence for their role in the control of cardiovascular function. J Chem Neuroanat. 2009; 38(3): 185-96. PubMed Abstract | Publisher Full Text

62. Xue B, Zhao $Y$, Johnson AK, et al:: Central estrogen inhibition of angiotensin Il-induced hypertension in male mice and the role of reactive oxygen species. Am J Physiol Heart Circ Physiol. 2008; 295(3): H1025-H1032. PubMed Abstract | Publisher Full Text | Free Full Text

63. Xue B, Badaue-Passos D Jr, Guo F, et al:: Sex differences and central protective effect of 17beta-estradiol in the development of aldosterone/ $\mathrm{NaCl}$-induced hypertension. Am J Physiol Heart Circ Physiol. 2009; 296(5): H1577-85. PubMed Abstract | Publisher Full Text | Free Full Text

64. Xue B, Zhang Z, Beltz TG, et al.: Estrogen receptor- $\beta$ in the paraventricular nucleus and rostroventrolateral medulla plays an essential protective role in aldosterone/salt-induced hypertension in female rats. Hypertension. 2013. 61(6): 1255-62.

PubMed Abstract | Publisher Full Text | Free Full Text 
65. Li Z, Hay M: 17-beta-estradiol modulation of area postrema potassium currents. J Neurophysiol. 2000; 84(3): 1385-91.

PubMed Abstract

66. Ciriello J, Roder S: 17ß-Estradiol alters the response of subfornical organ neurons that project to supraoptic nucleus to plasma angiotensin II and hypernatremia. Brain Res. 2013; 1526: 54-64. PubMed Abstract | Publisher Full Text

67. Pamidimukkala J, Hay M: $\mathbf{1 7}$ beta-Estradiol inhibits angiotensin II activation of area postrema neurons. Am J Physiol Heart Circ Physiol. 2003; 285(4): H1515-20. PubMed Abstract | Publisher Full Text

68. F Xue B, Zhang Z, Beltz TG, et al:: Genetic knockdown of estrogen receptoralpha in the subfornical organ augments ANG II-induced hypertension in female mice. Am J Physiol Regul Integr Comp Physiol. 2015; 308(6): R507-16. PubMed Abstract | Publisher Full Text | Free Full Text | F1000 Recommendation

69. Gingerich S, Krukoff TL: Estrogen in the paraventricular nucleus attenuates L-glutamate-induced increases in mean arterial pressure through estrogen receptor beta and NO. Hypertension. 2006; 48(6): 1130-6.

PubMed Abstract | Publisher Full Text

70. Shih CD: Activation of estrogen receptor beta-dependent nitric oxide signaling mediates the hypotensive effects of estrogen in the rostral ventrolateral medulla of anesthetized rats. J Biomed Sci. 2009; 16: 60 . PubMed Abstract | Publisher Full Text | Free Full Text

71. St-Louis J, Massicotte G: Chronic decrease of blood pressure by rat relaxin in spontaneously hypertensive rats. Life Sci. 1985; 37(14): 1351-7. PubMed Abstract | Publisher Full Text

72. F Ma S, Shen P, Burazin TC, et al:: Comparative localization of leucine-rich repeat-containing G-protein-coupled receptor-7 (RXFP1) mRNA and [33P]relaxin binding sites in rat brain: restricted somatic co-expression a clue to relaxin action? Neuroscience. 2006; 141(1): 329-44.

PubMed Abstract | Publisher Full Text | F1000 Recommendation

73. Mumford AD, Parry LJ, Summerlee AJ: Lesion of the subfornical organ affects the haemotensive response to centrally administered relaxin in anaesthetized rats. J Endocrinol. 1989; 122(3): 747-55. PubMed Abstract

74. F Sun HJ, Chen D, Han Y, et al:: Relaxin in paraventricular nucleus contributes to sympathetic overdrive and hypertension via PI3K-Akt pathway. Neuropharmacology. 2016; 103: 247-56. PubMed Abstract | Publisher Full Text | F1000 Recommendation

75. Stumpe KO, Kolloch R, Higuchi M, et al:: Hyperprolactinaemia and antihypertensive effect of bromocriptine in essential hypertension. Identification of abnormal central dopamine control. Lancet. 1977; 2(8031): 211-4.

PubMed Abstract | Publisher Full Text

76. Leaños-Miranda A, Márquez-Acosta J, Cárdenas-Mondragón GM, et al.: Urinary prolactin as a reliable marker for preeclampsia, its severity, and the occurrence of adverse pregnancy outcomes. J Clin Endocrinol Metab. 2008; 93(7): 2492-9.

PubMed Abstract | Publisher Full Text

77. Oney $\mathrm{T}$, Bellmann $\mathrm{O}$, Kaulhausen $\mathrm{H}$ : Relationship between serum prolactin concentration, vascular angiotensin sensitivity and arterial blood pressure during third trimester pregnancy. Arch Gynecol Obstet. 1988; 243(2): 83-90. PubMed Abstract | Publisher Full Text

78. F Zhang L, Curhan GC, Forman JP: Plasma prolactin level and risk of incident hypertension in postmenopausal women. J Hypertens. 2010; 28(7): 1400-5. PubMed Abstract | Publisher Full Text | Free Full Text | F1000 Recommendation

79. F Georgiopoulos GA, Stamatelopoulos KS, Lambrinoudaki I, et al:: Prolactin and preclinical atherosclerosis in menopausal women with cardiovascular risk factors. Hypertension. 2009; 54(1): 98-105.

PubMed Abstract | Publisher Full Text | F1000 Recommendation

80. Bole-Feysot C, Goffin V, Edery M, et al.: Prolactin (PRL) and its receptor: actions, signal transduction pathways and phenotypes observed in PRL receptor knockout mice. Endocr Rev. 1998; 19(3): 225-68. PubMed Abstract | Publisher Full Text

81. Patil MJ, Henry MA, Akopian AN: Prolactin receptor in regulation of neuronal excitability and channels. Channels (Austin). 2014; 8(3): 193-202. PubMed Abstract | Publisher Full Text | Free Full Text

82. Brown RS, Kokay IC, Herbison AE, et al.: Distribution of prolactin-responsive neurons in the mouse forebrain. J Comp Neurol. 2010; 518(1): 92-102. PubMed Abstract | Publisher Full Text

83. Hindmarch C, Fry M, Yao ST, et al:: Microarray analysis of the transcriptome of the subfornical organ in the rat: regulation by fluid and food deprivation. $A m$ Physiol Regul Integr Comp Physiol. 2008; 295(6): R1914-20. PubMed Abstract | Publisher Full Text

84. Durante W, Johnson FK, Johnson RA: Role of carbon monoxide in cardiovascular function. J Cell Mol Med. 2006; 10(3): 672-86.

PubMed Abstract | Publisher Full Text

85. Zhao Y, Vanhoutte PM, Leung SW: Vascular nitric oxide: Beyond eNOS. J Pharmacol Sci. 2015; 129(2): 83-94. PubMed Abstract | Publisher Full Text

86. Abe $\mathrm{K}$, Kimura $\mathrm{H}$ : The possible role of hydrogen sulfide as an endogenous neuromodulator. J Neurosci. 1996; 16(3): 1066-71. PubMed Abstract
87. Hosoki R, Matsuki N, Kimura $\mathrm{H}$ : The possible role of hydrogen sulfide as an endogenous smooth muscle relaxant in synergy with nitric oxide. Biochem Biophys Res Commun. 1997; 237(3): 527-31.

PubMed Abstract | Publisher Full Text

88. Kuo SM, Lea TC, Stipanuk MH: Developmental pattern, tissue distribution, and subcellular distribution of cysteine: alpha-ketoglutarate aminotransferase and 3-mercaptopyruvate sulfurtransferase activities in the rat. Biol Neonate. 1983; 43(1-2): 23-32.

PublMed Abstract

89. F Benavides GA, Squadrito GL, Mills RW, et al:: Hydrogen sulfide mediates the vasoactivity of garlic. Proc Natl Acad Sci U S A. 2007; 104(46): 17977-82. PubMed Abstract | Publisher Full Text | Free Full Text | F1000 Recommendation

90. Sun L, Sun S, Li Y, et al.: Potential biomarkers predicting risk of pulmonary hypertension in congenital heart disease: the role of homocysteine and hydrogen sulfide. Chin Med J (Engl). 2014; 127(5): 893-9. PubMed Abstract

91. Sun NL, Xi Y, Yang SN, et al:: [Plasma hydrogen sulfide and homocysteine levels in hypertensive patients with different blood pressure levels and complications]. Zhonghua Xin Xue Guan Bing Za Zhi. 2007; 35(12): 1145-8. PubMed Abstract

92. Wang C, Han J, Xiao L, et al.: Role of hydrogen sulfide in portal hypertension and esophagogastric junction vascular disease. World J Gastroenterol. 2014; 20(4): 1079-87.

PubMed Abstract | Publisher Full Text | Free Full Text

93. Holwerda KM, Bos EM, Rajakumar A, et al.: Hydrogen sulfide producing enzymes in pregnancy and preeclampsia. Placenta. 2012; 33(6): 518-21. PubMed Abstract | Publisher Full Text

94. Wang K, Ahmad S, Cai M, et al.: Dysregulation of hydrogen sulfide producing enzyme cystathionine $\gamma$-lyase contributes to maternal hypertension and placental abnormalities in preeclampsia. Circulation. 2013; 127(25): 2514-22. PubMed Abstract | Publisher Full Text

95. d'Emmanuele di Villa Bianca R, Sorrentino R, Coletta C, et al.: Hydrogen sulfide-induced dual vascular effect involves arachidonic acid cascade in rat mesenteric arterial bed. J Pharmacol Exp Ther. 2011; 337(1): 59-64. PubMed Abstract | Publisher Full Text

96. Baragatti $B$, Ciofini $E$, Sodini $D$, et al.: Hydrogen sulfide in the mouse ductus arteriosus: a naturally occurring relaxant with potential EDHF function. $A m J$ Physiol Heart Circ Physiol. 2013; 304(7): H927-34.

PubMed Abstract | Publisher Full Text

97. Martelli A, Testai L, Breschi MC, et al:: Vasorelaxation by hydrogen sulphide involves activation of $\mathrm{K}_{\mathrm{v}} 7$ potassium channels. Pharmacol Res. 2013; 70(1): 27-34.

PubMed Abstract | Publisher Full Text

98. Ariyaratnam $\mathrm{P}$, Loubani $\mathrm{M}$, Morice $\mathrm{AH}$ : Hydrogen sulphide vasodilates human pulmonary arteries: a possible role in pulmonary hypertension? Microvasc Res. 2013; 90: 135-7. PubMed Abstract | Publisher Full Text

99. Jackson-Weaver O, Osmond JM, Riddle MA, et al:: Hydrogen sulfide dilates rat mesenteric arteries by activating endothelial large-conductance $\mathrm{Ca}^{2+}$-activated $\mathrm{K}^{+}$channels and smooth muscle $\mathrm{Ca}^{2+}$ sparks. Am J Physiol Heart Circ Physiol. 2013; 304(11): H1446-54.

PubMed Abstract | Publisher Full Text | Free Full Text

100. Zhao W, Zhang J, Lu Y, et al:: The vasorelaxant effect of $\mathrm{H}_{2} \mathrm{~S}$ as a novel endogenous gaseous $K_{A T P}$ channel opener. EMBO J. 2001; 20(21): 6008-16. PubMed Abstract | Publisher Full Text | Free Full Text

101. Ahmad FU, Sattar MA, Rathore $H A$, et al:: Exogenous hydrogen sulfide $\left(\mathbf{H}_{2} \mathbf{S}\right)$ reduces blood pressure and prevents the progression of diabetic nephropathy in spontaneously hypertensive rats. Ren Fail. 2012; 34(2): 203-10. PubMed Abstract | Publisher Full Text

102. Ahmad FU, Sattar MA, Rathore HA, et al:: Hydrogen sulphide and tempol treatments improve the blood pressure and renal excretory responses in spontaneously hypertensive rats. Ren Fail. 2014; 36(4): 598-605. PubMed Abstract | Publisher Full Text

103. Li L, Whiteman M, Guan YY, et al:: Characterization of a novel, water-soluble hydrogen sulfide-releasing molecule (GYY4137): new insights into the biology of hydrogen sulfide. Circulation. 2008; 117(18): 2351-60. PubMed Abstract | Publisher Full Text

104. Yan $\mathrm{H}, \mathrm{Du} \mathrm{J}$, Tang $\mathrm{C}$ : The possible role of hydrogen sulfide on the pathogenesis of spontaneous hypertension in rats. Biochem Biophys Res Commun. 2004; 313(1): 22-7. PubMed Abstract | Publisher Full Tex

105. F Yang G, Wu L, Jiang B, et al:: $\mathbf{H}_{2} \mathbf{S}$ as a physiologic vasorelaxant: hypertension in mice with deletion of cystathionine gamma-lyase. Science. 2008; 322(5901): 587-90.

PubMed Abstract | Publisher Full Text | Free Full Text | F1000 Recommendation

106. Ren YS, Wu SY, Wang XJ, et al:: Multiple hemodynamic effects of endogenous hydrogen sulfide on central nervous system in rats. Chin Med J (Engl). 2011; 124(21): 3468-75 PubMed Abstract | Publisher Full Text

107. Guo Q, Jin S, Wang XL, et al:: Hydrogen sulfide in the rostral ventrolatera medulla inhibits sympathetic vasomotor tone through ATP-sensitive $\mathrm{K}^{+}$ channels. J Pharmacol Exp Ther. 2011; 338(2): 458-65. PubMed Abstract | Publisher Full Text 
108. Gan XB, Liu TY, Xiong XQ, et al:: Hydrogen sulfide in paraventricular nucleus enhances sympathetic activity and cardiac sympathetic afferent reflex in chronic heart failure rats. PLoS One. 2012; 7(11): e50102. PubMed Abstract | Publisher Full Text | Free Full Text

109. Kuksis M, Smith PM, Ferguson AV: Hydrogen sulfide regulates cardiovascular function by influencing the excitability of subfornical organ neurons. PLOS One. 2014; 9(8): e105772. PubMed Abstract | Publisher Full Text | Free Full Text

110. Malik R, Ferguson AV: Hydrogen sulfide depolarizes neurons in the nucleus of the solitary tract of the rat. Brain Res. 2016; 1633: 1-9. PubMed Abstract | Publisher Full Text

111. Khademullah CS, Ferguson AV: Depolarizing actions of hydrogen sulfide on hypothalamic paraventricular nucleus neurons. PLoS One. 2013; 8(5): e64495. PubMed Abstract | Publisher Full Text | Free Full Text

112. Rodrigo $\mathrm{R}$, Libuy $\mathrm{M}$, Feliú $\mathrm{F}$, et al:: Oxidative stress-related biomarkers in essential hypertension and ischemia-reperfusion myocardial damage. Dis Markers. 2013; 35(6): 773-90. PubMed Abstract | Publisher Full Text | Free Full Text

113. Rodrigo R, Prat $\mathrm{H}$, Passalacqua W, et al:: Relationship between oxidative stress and essential hypertension. Hypertens Res. 2007; 30(12): 1159-67. PubMed Abstract | Publisher Full Text

114. F Cowley AW Jr, Yang C, Zheleznova NN, et al.: Evidence of the Importance of Nox4 in Production of Hypertension in Dahl Salt-Sensitive Rats. Hypertension. 2016; 67(2): 440-50.

PubMed Abstract | Publisher Full Text | Free Full Text | F1000 Recommendation

115. Dikalova $A$, Clempus $R$, Lassègue $B$, et al:: Nox1 overexpression potentiates angiotensin II-induced hypertension and vascular smooth muscle hypertrophy in transgenic mice. Circulation. 2005; 112(17): 2668-76.

PubMed Abstract | Publisher Full Text
116. Braga VA, Colombari E, Jovita MG: Angiotensin II-derived reactive oxygen species underpinning the processing of the cardiovascular reflexes in the medulla oblongata. Neurosci Bull. 2011; 27(4): 269-74.

PubMed Abstract | Publisher Full Text

117. Braga VA, Medeiros IA, Ribeiro TP, et al:: Angiotensin-II-induced reactive oxygen species along the SFO-PVN-RVLM pathway: implications in neurogenic hypertension. Braz J Med Biol Res. 2011; 44(9): 871-6. PubMed Abstract | Publisher Full Text

118. F Kishi T, Hirooka $Y$, Kimura $Y$, et al:: Increased reactive oxygen species in rostral ventrolateral medulla contribute to neural mechanisms of hypertension in stroke-prone spontaneously hypertensive rats. Circulation. 2004; 109(19): 2357-62.

PubMed Abstract | Publisher Full Text | F1000 Recommendation

119. Zimmerman MC, Lazartigues E, Lang JA, et al:: Superoxide mediates the actions of angiotensin II in the central nervous system. Circ Res. 2002; 91(11): 1038-45. PubMed Abstract | Publisher Full Text

120. F Lob HE, Marvar PJ, Guzik TJ, et al.: Induction of hypertension and peripheral inflammation by reduction of extracellular superoxide dismutase in the central nervous system. Hypertension. 2010; 55(2): 277-83, 6p following 283. PubMed Abstract | Publisher Full Text | Free Full Text | F1000 Recommendation

121. Halaas JL, Gajiwala KS, Maffei M, et al.: Weight-reducing effects of the plasma protein encoded by the obese gene. Science. 1995; 269(5223): 543-6. PubMed Abstract | Publisher Full Text

122. Carmichael CY, Wainford RD: Hypothalamic signaling mechanisms in hypertension. Curr Hypertens Rep. 2015; 17(5): 39. PubMed Abstract | Publisher Full Text | Free Full Text

123. Stump M, Mukohda M, Hu C, et al:: PPAR $\gamma$ Regulation in Hypertension and Metabolic Syndrome. Curr Hypertens Rep. 2015; 17(12): 89 PubMed Abstract | Publisher Full Text 


\section{Open Peer Review}

\section{Current Peer Review Status:}

\section{Editorial Note on the Review Process}

Faculty Reviews are review articles written by the prestigious Members of Faculty Opinions. The articles are commissioned and peer reviewed before publication to ensure that the final, published version is comprehensive and accessible. The reviewers who approved the final version are listed with their names and affiliations.

\section{The reviewers who approved this article are:}

\section{Version 1}

\section{John Ciriello}

Department of Physiology and Pharmacology, Schulich School of Medicine and Dentistry, University of Western Ontario, London, Ontario, Canada

Competing Interests: No competing interests were disclosed.

\section{Leo Renaud}

Neuroscience Program, Ottawa Hospital Research Institute and Department of Medicine, University of Ottawa, Ottawa, Ontario, Canada

Competing Interests: No competing interests were disclosed.

The benefits of publishing with F1000Research:

- Your article is published within days, with no editorial bias

- You can publish traditional articles, null/negative results, case reports, data notes and more

- The peer review process is transparent and collaborative

- Your article is indexed in PubMed after passing peer review

- Dedicated customer support at every stage

For pre-submission enquiries, contact research@f1000.com

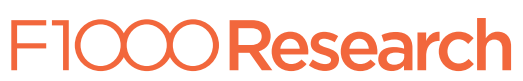

